\title{
PEMANFAATAN KOTORAN KAMBING PADA BUDIDAYA TANAMAN BUAH DALAM POT UNTUK MENDUKUNG PERKEMBANGAN PONDOK PESANTREN
}

\author{
Mujiyo dan Suryono \\ Program Studi Ilmu Tanah, Fakultas Pertanian, Universitas Sebelas Maret Surakarta \\ Email : mujiyo_wa@yahoo.com
}

\begin{abstract}
ABSTRAK
Program IbM ini bekerjasama dengan dua mitra, yaitu: (1) UKM Peternakan Kambing "Maendo Mulyo", dan (2) Pondok Pesantren "Al Mukhlishin". Mitra (1) berlokasi di Desa Bakalan Desa Ngadirejo, Kecamatan Mojogedang, Kabupaten Karanganyar yang berjarak tempuh sekitar 25 km dari Fakultas Pertanian UNS. Bidang usaha yang dikembangkan oleh mitra (1) tersebut adalah usaha kambing. Sedangkan Mitra (2) berlokasi di Desa Tegalgede Kecamatan Karanganyar Kabupaten Karanganyar. Pondok Pesantren Al Muklishin tergolong Pondok Pesantren Salafiyah; yang masih tetap mempertahankan sistem pendidikan khas Pondok Pesantren, baik kurikulum maupun metode pendidikannya. Selain kegiatan Keagamaan, PonPes Al Muklishin juga megadakan kegiatan lain diantaranya adalah pertanian. Permasalahan Mitra 1 (UKM Peternakan Kambing "Maendo Mulyo") : Mitra 1 dalam kegiatan IbM ini menghadapi permasalahan utama yaitu banyaknya kotoran kambing yang belum termanfaatkan, produksi limbah ternak kambing (kotoran kambing) yang sangat tinggi, yaitu sekitar $50 \mathrm{~kg}$ limbah per hari (1,5 ton per bulan), dan jika hal ini dibiarkan akan menjadi tumpukan kotoran kambing yang sangat berbau dan dapat mengundang lalat sebagai penular berbagai macam penyakit, apabila dikelola/diolah/difermentasi bisa digunakan sebagai pupuk organik yang sangat bermutu. Dalam usaha peternakan kambing ini ingin mengarah pada peternakan yang ramah lingkungan sehingga tidak menjadi masalah di masyarakat. Permasalahan Mitra 2 (Ponpes "Al Mukhlishin") : Mitra 2 dalam kegiatan IbM ini menghadapi permasalahan utama yaitu tingginya kebutuhan buah harian untuk santri mukim sejumlah 95 orang yang diasuh oleh 4 orang guru pondok tetap. Oleh karena itu diperlukan penyediaan buah secara mandiri yang harganya lebih murah, seperti buah organik yang ditanam dalam pot dengan memanfaatkan pupuk dari kotoran kambing yang dibuat dengan menggunakan kotoran ternak kambing yang belum dimanfaatkan. Solusi yang ditawarkan untuk mengatasi permasalahan utama yang dihadapi mitra (1) adalah teknologi pembuatan pupuk organik yang dapat digunakan sebagai pupuk organik yang sangat bermutu yang dapat digunakan sebagai pupuk organik bagi usaha budidaya buah organik dalam pot pada mitra (2).
\end{abstract}

Kata kunci : $\quad$ kotoran kambing, pupuk organik, budidaya buah organik, pondok pesantren

\section{PENDAHULUAN}

\section{Analisis Situasi}

Program IbM ini bekerjasama dengan dua mitra, yaitu: (1) UKM Peternakan Kambing "Maendo Mulyo", dan (2) Pondok Pesantren "Al Mukhlishin". Mitra (1) berlokasi di Desa Bakalan Desa Ngadirejo, Kecamatan Mojogedang, Kabupaten Karanganyar yang berjarak tempuh sekitar $25 \mathrm{~km}$ dari Fakultas Pertanian UNS. Bidang usaha yang dikembangkan oleh mitra (1) tersebut adalah usaha kambing. Sedangkan Mitra (2) berlokasi di Desa Tegalgede Kecamatan Karanganyar Kabupaten Karanganyar. Pondok Pesantren Al
Muklishin tergolong Pondok Pesantren Salafiyah; yang masih tetap mempertahankan sistem pendidikan khas Pondok Pesantren, baik kurikulum maupun metode pendidikannya. Selain kegiatan Keagamaan, Pondok Pesantren Al Muklishin juga mengadakan kegiatan lain diantaranya adalah pertanian. Mitra berjarak tempuh sekitar $17 \mathrm{~km}$ dari Fakultas Pertanian UNS

UKM Peternakan Kambing "Maendo Mulyo" merupakan usaha mikro milik Sunarso. Lokasi usaha ini berada di Desa Bakalan Desa Ngadirejo, Kecamatan Mojogedang, Kabupaten Karanganyar. Manajemen usaha yang 
dikembangkan berdasarkan manajemen usaha keluarga. 'Maendo Mulyo' mempekerjakan 1 orang tenaga kerja. Kegiatan usaha yang dikembangkan menempati areal seluas sekitar $450 \mathrm{~m}^{2}$, dengan jenis usaha Peternakan Kambing.

Peternakan kambing terdiri dari 1 unit rumah kambing, dengan populasi kambing 16 ekor. Usaha kambing ini telah mensejahterakan keluarga, dan memberikan penghasilan ekonomi tambahan yang bisa digunakan pada saat membutuhkan dengan kebutuhan besar. Namun demikian, mereka belum mampu melayani permintaan kambing yang tinggi dari konsumen di Karanganyar dan sekitarnya pada saat Idul Adha/ Kurban, sehingga usaha ini memiliki potensi berkembang secara berkelanjutan di masa yang akan datang.

Pondok Pesantren Al Muklishin terletak di Kompleks Masjid Baitul Karim dengan Luas Lahan sekitar $7000 \mathrm{~m}^{2}$. Pondok Pesantren Al Muklishin tergolong Pondok Pesantren Salafiyah; Pondok Pesantren Al Muklishin masih tetap mempertahankan sistem pendidikan khas Pondok Pesantren, baik kurikulum maupun metode pendidikannya. Bahan ajar meliputi ilmu-ilmu agama Islam, dengan mempergunakan kitab-kitab klasik berbahasa Arab, sesuai dengan tingkat kemampuan masing-masing santri. Pembelajaran dengan cara bandongan dan sorogan masih tetap dipertahankan, tetapi sudah banyak yang menggunakan sistem klasikal. Selain kegiatan Keagamaan, PonPes Al Muklishin juga megadakan kegiatan lain diantaranya pertanian dan ketrampilan. Saat ini Pondok Pesantren Al Muklishin mempunyai 95 orang santri mukim dengan lebih dari 150 santri yang tidak mukim, dan diasuh oleh 4 orang guru pondok tetap.

\section{Permasalahan Mitra}

Permasalahan Mitra 1 (UKM Peternakan Kambing "Maendo Mulyo") : mitra usaha 1 dalam kegiatan IbM ini menghadapi permasalahan utama yaitu banyaknya kotoran kambing yang belum termanfaatkan, produksi limbah ternak kambing (kotoran kambing) yang sangat tinggi, yaitu sekitar $50 \mathrm{~kg}$ limbah per hari (1,5 ton per bulan), dan jika hal ini dibiarkan akan menjadi tumpukan kotoran kambing yang sangat berbau dan dapat mengundang lalat sebagai penular berbagai macam penyakit, apabila dikelola/diolah/difermentasi bisa digunakan sebagai pupuk organik yang sangat bermutu. Dalam usaha peternakan kambing ini ingin mengarah pada peternakan yang ramah lingkungan sehingga tidak menjadi masalah di masyarakat.

Permasalahan Mitra 2 (Pondok Pesantren "Al Mukhlishin") : mitra usaha 2 dalam kegiatan IbM ini menghadapi permasalahan utama yaitu tingginya kebutuhan buah untuk mencukupi kebutuhan gizi santri mukim sejumlah 95 orang. Oleh karena itu diperlukan penyediaan buah alternatif yang harganya lebih murah, seperti buah organik dalam pot yang dapat ditanam sendiri dengan menggunakan pupuk organik dari kotoran ternak kambing yang belum dimanfaatkan sehingga didapatkan sayur yang sehat dan bergizi.

\section{BAHAN DAN METODE}

\section{Metode Pelaksanaan}

Metode yang digunakan untuk mengatasi permasalahan utama yang dihadapi mitra (1) adalah teknologi pembuatan pupuk organik yang dapat digunakan sebagai bahan pupuk organik dengan melalui teknologi komposting menggunakan starbio. Pemanfaatan kotoran kambing untuk bahan pembuatan pupuk organik merupakan wujud nyata dari penerapan peniadaan limbah pada peternakan kambing sehingga tidak mencemari lingkungan.

Sedangkan Metode yang digunakan untuk mengatasi permasalahan utama yang dihadapi mitra (2) adalah menggunakan pupuk organik yang dihasilkan dari proses komposting limbah kotoran kambing untuk budidaya buah organik dalam pot yang ramah lingkungan dan menguntungkan untuk 
Tabel 1. Tabel Unsur Hara Kotoran Sapi, Kambing, Domba dan Ayam

\begin{tabular}{lllllllll}
\hline Jenis Hewan & \multicolumn{3}{l}{ Unsur makro (\%) } & \multicolumn{7}{c}{ Unsur Mikro (ppm) } \\
\cline { 2 - 9 } & $\mathrm{N}$ & $\mathrm{P}$ & $\mathrm{K}$ & $\mathrm{Ca}$ & $\mathrm{Mn}$ & $\mathrm{Fe}$ & $\mathrm{Cu}$ & $\mathrm{Zn}$ \\
\hline Ayam & 1,72 & 1,82 & 2,18 & 9,23 & 610 & 3475 & 160 & 501 \\
Sapi & 2,04 & 0,76 & 0,82 & 1,29 & 520 & 2597 & 56 & 239 \\
Kambing & 2,43 & 0,73 & 1,35 & 1,95 & 468 & 2891 & 42 & 291 \\
Domba & 2,03 & 1,42 & 1,65 & 2,45 & 490 & 2188 & 23 & 225 \\
\hline
\end{tabular}

Sumber : Organic Vegetable Cultivation in Malaysia (2005)

mendukung kemandirian dan jiwa wirausaha santri serta perkembangan pondok pesantren.

Sebagai lembaga pendidikan yang telah lama berurat akar di negeri ini, pondok pesantren diakui memiliki andil yang sangat besar terhadap perjalanan sejarah bangsa (Haedari, 2007). Dalam proses belajar di Pondok pesantren para santri membutuhkan asupan gizi yang cukup yang berasal dari makanan yang dikonsumsi. Makanan diperlukan karena dari makanan didapatkan energy (tenaga) yang diperlukan untuk melangsungkan berbagai fungsi tubuh (Azwar,1990). Sehingga dibutuhkan makanan yang cukup dan sehat, salah satunya adalah melalui sayur yang ditanam secara organik dengan menggunakan pupuk organik berbahan dasar limbah kotoran kambing.

Limbah kotoran kambing merupakan gabungan antara kotoran kambing dan limbah pakan, sehingga mengandung berbagai senyawa organik dan unsur-unsur lain yang bermanfaat bagi kehidupan cacing tanah.

Kualitas pupuk kotoran kambing akan semakin bagus jika pencampuran kotoran kambing sebelum proses fermentasi di mulai. Peningkatan kandungan unsur hara baik makro atau mikro akan mengalami peningkatan dan lebih komplek berkat mancampur pupuk kandang dari sapi dan kotoran kambing.

Seperti tabel komposisi kandungan kimiawi makro \& mikro antara kotoran hewan sapi dan kambing memiliki keunggulan pada unsur makro Nitrogen (N), Kalium (K) serta kalsium (Ca). Namun semui itu tergantung juga, dari jenis tanaman apa yang akan di pupuk menggunakan bokashi yang terbuat dari campuran kotoran sapi dan kambing. Hasil analisis kandungan nutrisi dalam limbah ternak kambing seperti tercantum dalam Tabel 1 .

Pupuk merupakan bahan yang ditambahkan ke dalam tanah untuk menyediakan unsur hara yang penting bagi pertumbuhan tanaman. Penggolongan pupuk umumnya didasarkan pada sumber bahan yang digunakan, cara aplikasi, bentuk dan kandungan unsur haranya. (Hadisuwito,2012)

Pupuk organik mempunyai karakteristik kandungan hara rendah, ketersediaan unsur hara lambat, dan menyediakan hara dalam jumlah terbatas dan hara rendah. Ada beberapa manfaat pupuk yang berkaitan dengan sifat kimia tanah. Manfaat pupuk yang paling banyak dirasakan penggunaannnya adalah : menyediakan unsur hara yang diperlukan bagian tanaman, membantu mencegah kehilangan unsur hara yang cepat hilang seperti nitrogen, fosfor dan kalium., memperbaiki keasaman tanah (Marsono, 2001).

\section{Rencana Kegiatan dan Langkah-langkah Pelaksanaan}

Adapun kegiatan yang direncanakan meliputi: Survey awal untuk mengetahui tingkat pengetahuan mitra, kondisi lingkungan dan proses perijinan; Koordinasi dengan mitra untuk menentukan waktu, tempat pelaksanaan serta materi yang dibutuhkan mitra, Penyiapan peralatan dan perlengkapan pembuatan pupuk organik berbahan dasar kotoran kambing; Praktek pembuatan pupuk organik dengan memanfaatkan kotoran kambing yang dikomposkan dengan menggunakan starbio/bakteri dekomposer yang dapat 
membuat unsur-unsur hara lebih tersedia bagi tanaman dan dapat digunakan sebagai pupuk organic; Penyiapan peralatan dan perlengkapan penanaman buah organik dalam pot dengan memanfaatkan pupuk organik berbahan dasar kotoran kambing yang telah dihasilkan; Praktek budidaya buah organik dalam pot oleh santri pondok pesantren dengan memanfaatkan pupuk organik berbahan dasar kotoran kambing yang telah dihasilkan.

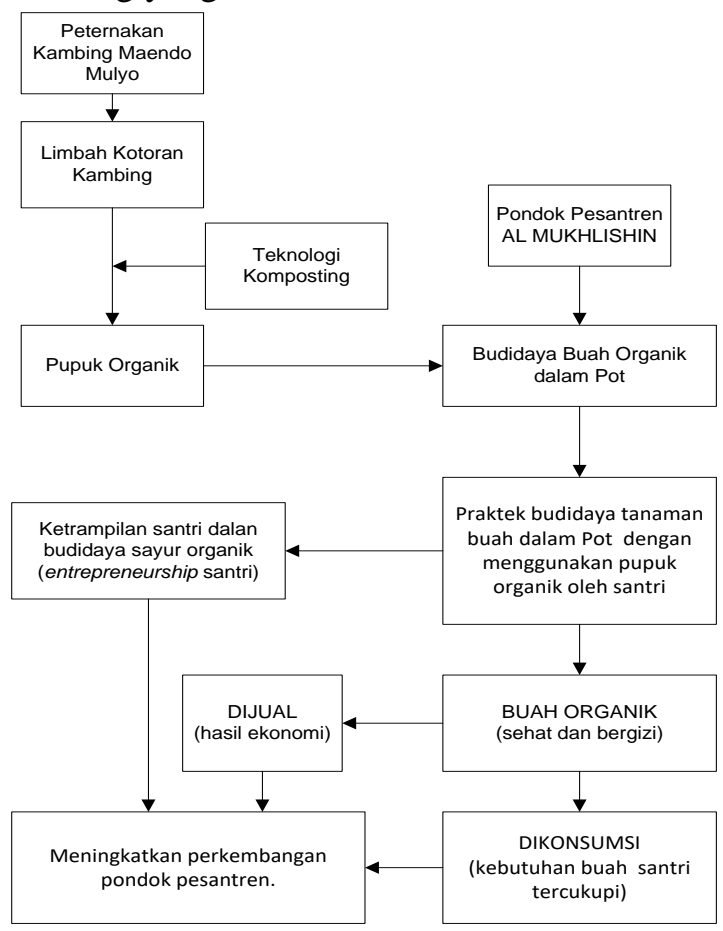

Gambar 1 Gambaran Ipteks yang akan ditransfer kepada kedua mitra

\section{Partisipasi Mitra Dalam Pelaksanaan Program}

Partisipasi mitra dalam pelaksanakan program IbM ini meliputi: Penyediaan kotoran kambing sebagai bahan pembuatan pupuk organic; Penyediaan lokasi penerapan pupuk organik dari kotoran kambing untuk budidaya buah dalam pot; Penyediaan sumberdaya manusia sebagi subyek untuk dilatih berbagai kegiatan program ini.

\section{HASIL YANG DICAPAI}

Hasil yang dicapai pada kegiatan pengabdian ini menjadi solusi yang ditawarkan untuk mengatasi permasalahan utama yang dihadapi mitra (1) Peternak Kambing Maendo Mulyo adalah teknologi pembuatan pupuk organik yang dapat digunakan sebagai pupuk organik yang sangat bermutu yang dapat digunakan sebagai pupuk organik bagi usaha budidaya buah organik dalam pot pada mitra (2) Pondok Pesantren Al Mukhlishin. Adapun rangkaian kegiatan pengabdian yang dilakukan disajikan pada foto-foto di bawah ini.

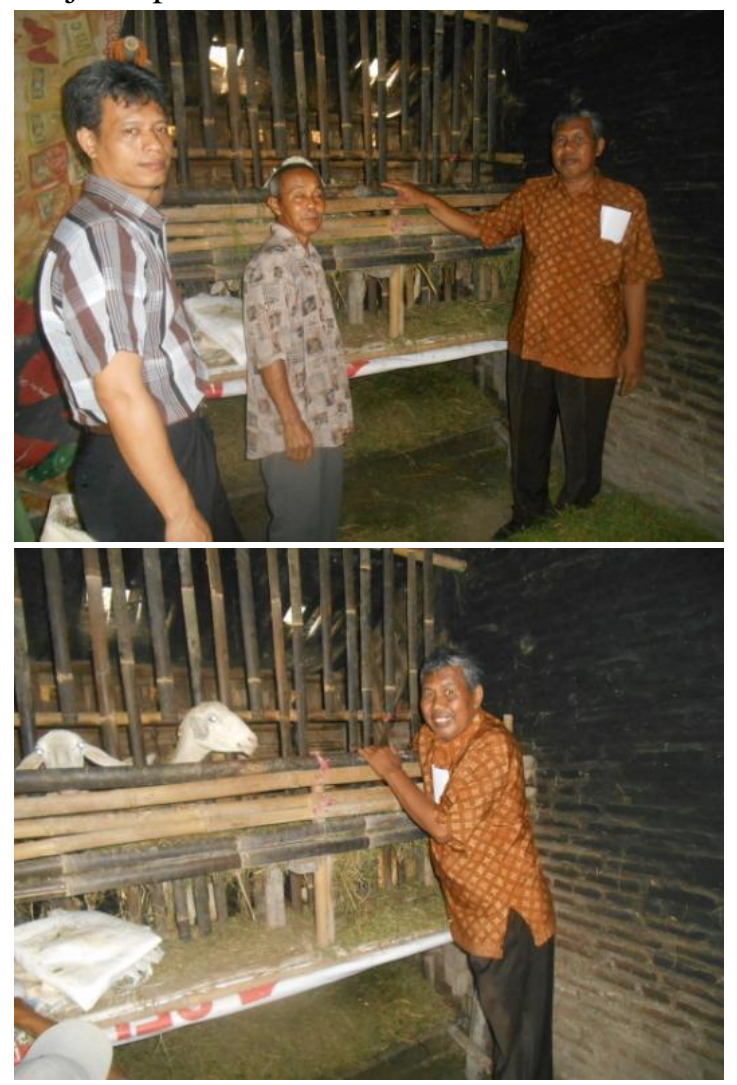

Kordinasi dengan peternak kambing

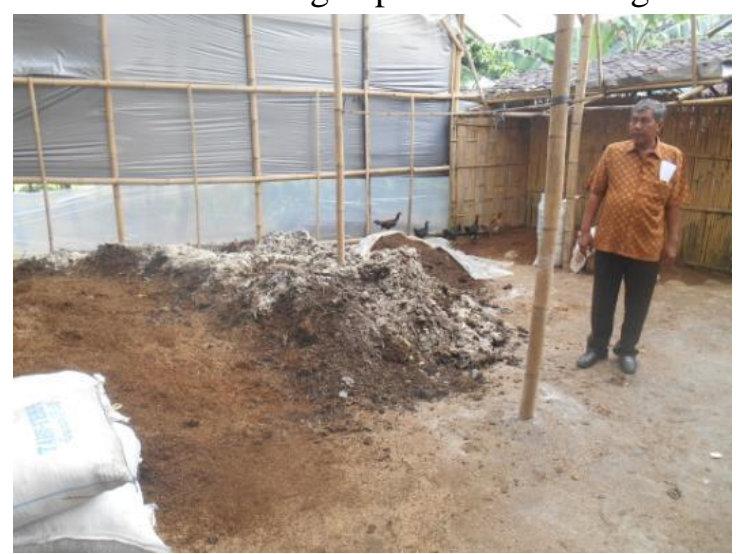

Pembuatan pupuk organik 
Pemanfaatan Kotoran Kambing pada Budidaya Tanaman Buah ... Mujiyo dan Suryono

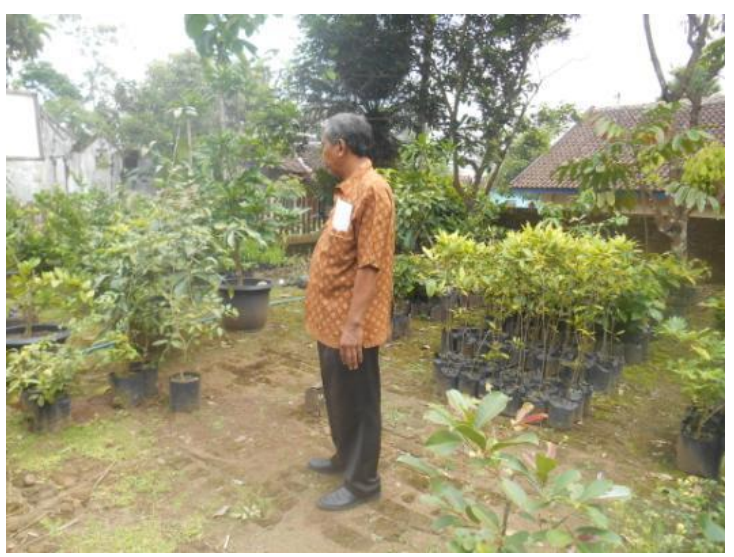

Persiapan bibit

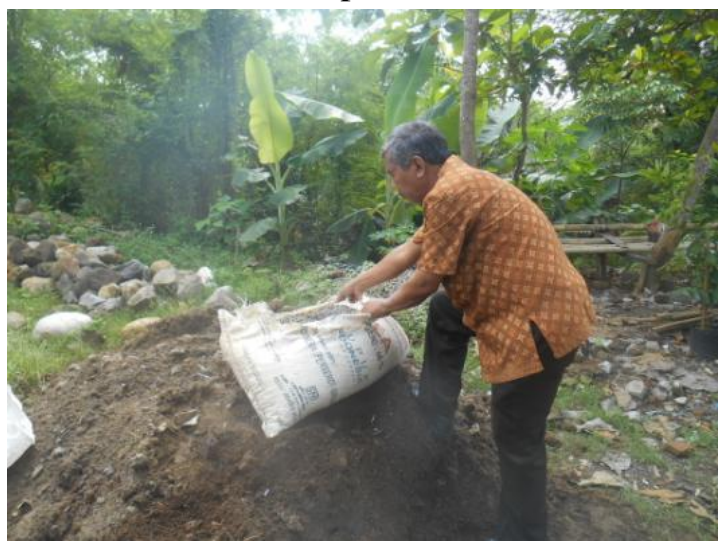

Persiapan tanah dan pupuk

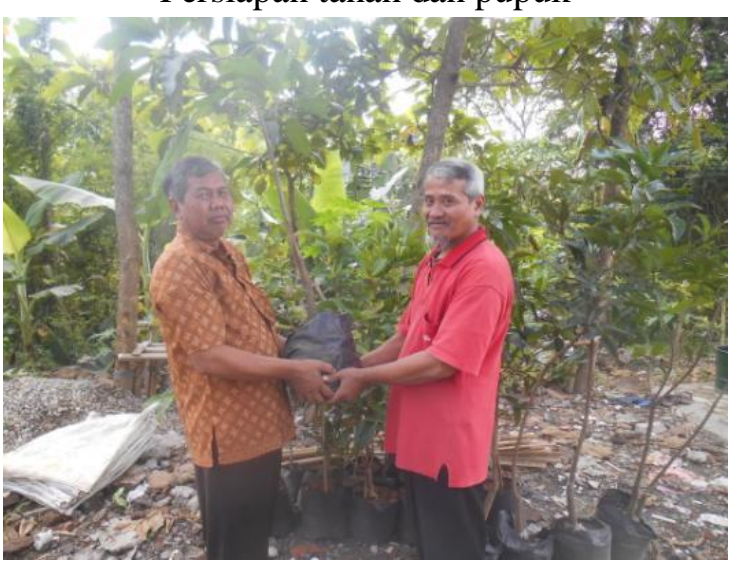

Penyerahan bantuan bibit tanaman buah

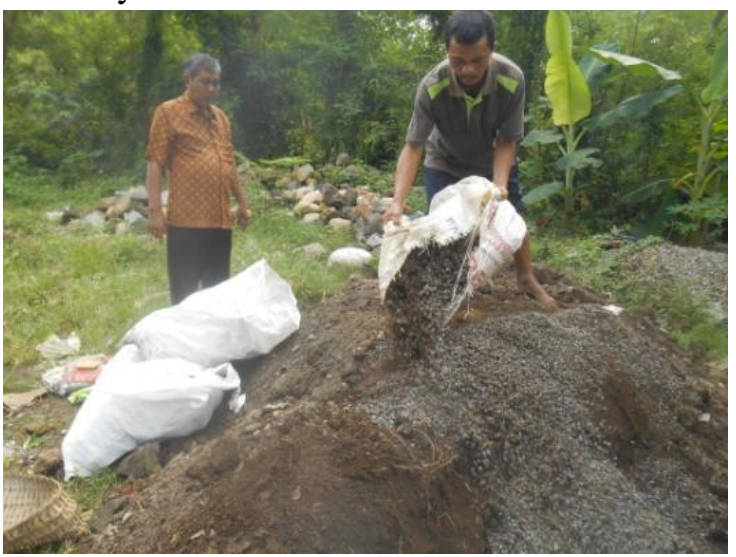

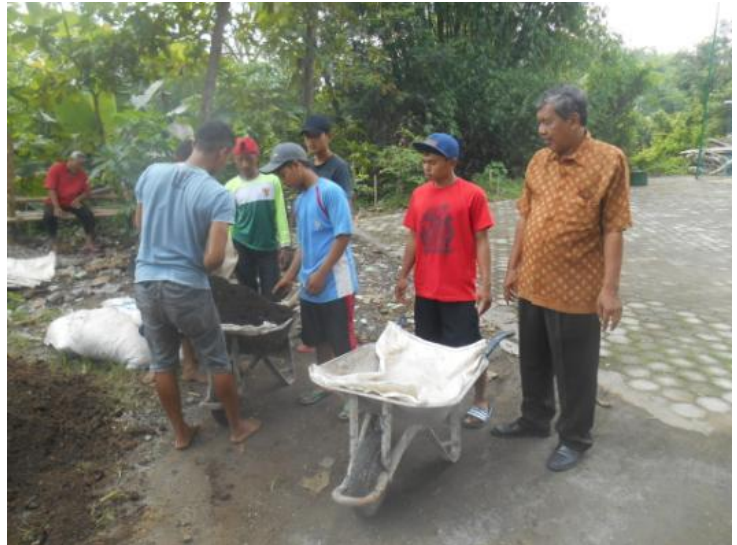

Persiapan media tanam

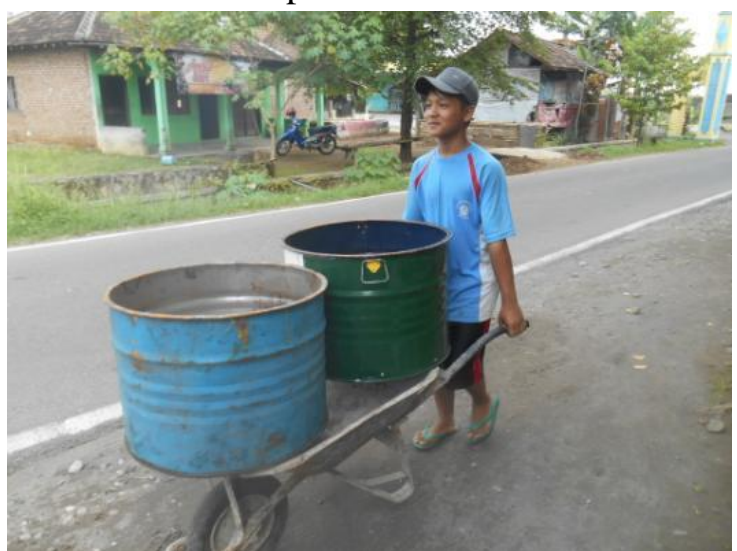

Persiapan tempat penanaman
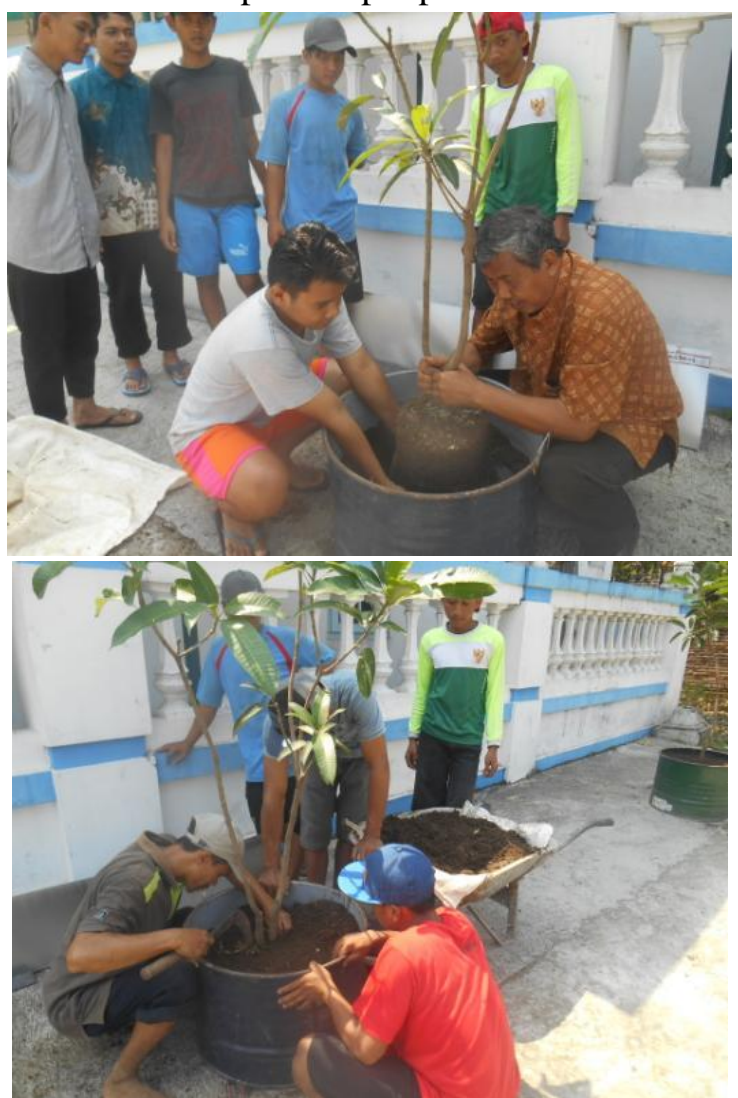

Proses penanaman 


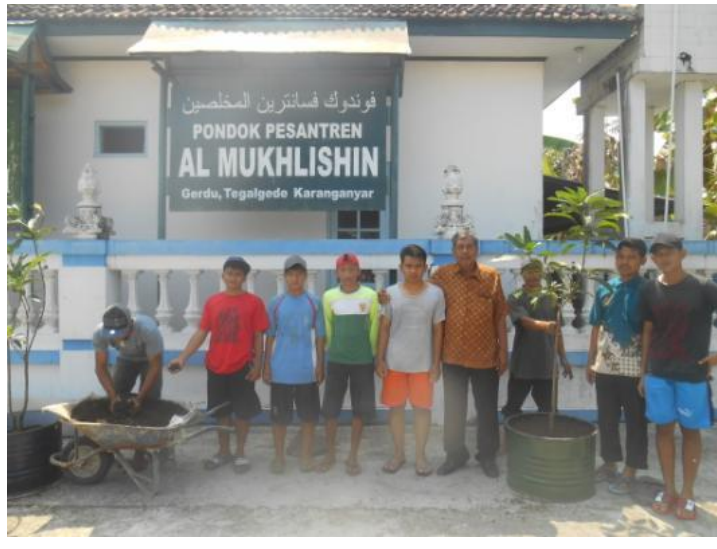

Foto bersama

\section{KESIMPULAN DAN SARAN}

Teknologi pembuatan pupuk organik yang dapat digunakan sebagai pupuk organik yang sangat bermutu yang dapat digunakan sebagai pupuk organik bagi usaha budidaya buah organik dalam pot sehingga dapat mengatasi masalah yang dihadapi.

\section{UCAPAN TERIMA KASIH}

Ucapan terima kasih disampaikan kepada Universitas Sebelas Maret yang telah mendanai kegiatan IbM ini melalui Dana PNBP Universitas Sebelas Maret Tahun Anggaran 2016. Ucapan terima kasih juha disampaikan kepada Pondok Pesantren Al Mukhlishin dan UKM Peternak Kambing Maendo Mulyo yang telah bersedia menjadi mitra dan mendukung kegiatan IbM ini.

\section{DAFTAR PUSTAKA}

Anggraeni, I. 2009. Efisiensi Serapan N dan Hasil Tanaman Padi (Oryza sativa L.) Pada Berbagai Imbangan Pupuk Kandang Kambing dan Pupuk Anorganik Di Lahan Sawah Palur Sukoharjo (Musim Tanam II). Skripsi S1. Fak. Pertanian UNS. Surakarta.

Azwar. A. 1990. Pengantar Ilmu Kesehatan Lingkungan. Jakarta: Mutiara Sumber Widya.

Hadisuwito, Sukamto. 2012. Membuat Pupuk Organik Cair. Jakarta : Agromedia Pustaka:.

Haedari, 2007. Transformasi Pesantren. Jakarta : Media Nusantara.

Marsono, Sigit P. 2001. Pupuk Akar: Jenis dan Aplikasi. Jakarta: PT. Penebar Swadaya 